\title{
Diaspora mezi snem a realitou. Znovuobjevená společenství pro transnacionální svět?
}

\author{
Diaspora Between Dream and Reality. Reinvented Societies in the \\ Transnational World?
}

\author{
Eleonóra Hamar
}

ABSTRACT In the early nineteenths diaspora has become a key concept in post-colonial studies and since that time is frequently used also in cultural and global studies focusing on the recent condition of transnational flows. In this text I analyze the diaspora as a "wandering" social structure via interpreting the diaspora theory of Jonathan and Daniel Boyarin, which takes the diaspora both as condition and project for a transnationally interconnected world. I show what role memory and remembering plays in their redefinition of the genealogical diasporic group identity and in what sense it is offered as a positive alternative to group identity based on territoriality. Finally I tackle the problem of powers of diaspora to demonstrate what risks are being reproduced by the unreflective universalizing of diaspora and by its decontextualized utilization.

KEY WORDS diaspora, genealogy, generation, Jewish identities, memory, transnational identities, wandering

\begin{abstract}
Náhodou jsem se ocitl $\mathrm{v}$ neděli odpoledne $\mathrm{v}$ Brooklynu několik hodin před pohřbem rabína Schneersona. Podzemka měla ten den výpadky, a tak jsem na stanici Atlantic Avenue strávil spoustu času čekáním na př́ípoj. Zastávkou projíždí tř̌etí i čtvrtá linka metra, každá staví na jiném nástupišti, jež jsou vzájemně na dohled. Ve stejné době čekaly už pěkně dlouho stovky Chasidů - převážně mladých mužů a soudě podle detailů jejich oblečení to nebyli Lubavičové - na třetí linku na nástupišti př́mo naproti mě. Jak tam tak stáli, přijela na nástupiště, na kterém jsem stál já, rozmrzelý a unavený z velkého horka, čtyřka směřující na stanici Crown Heights. Jakmile ji spatřili, začali se hromadně hrnout dolů po schodech, přes mé nástupiště, po schodech nahoru a do vozu, jehož průvodčí několik minut čekal, dokud se všem nepodařilo do soupravy nastoupit. Když už byl konečně připraven odjet, objevila se na schodech chasidská žena zralého středního věku a ze všech sil se hnala nahoru, volajíce prritom v jidiš Halt di tir ofn! - „Nech ty dveře otevřené!“
\end{abstract}

(Jonathan Boyarin 1996: 182)

Tímto krátkým etnografickým popisem končí Jonathan Boyarin jeden ze svých esejů, v němž se zamýšlí nad budoucností židovských společenství ve světě, v němž se představa uzavřených a monokulturních národních celků objevuje nanejvýš ve snech příslušníků radikálních

Sociální studia. Fakulta sociálních studií Masarykovy univerzity, 1/2006. S. 129-143. ISSN 1214-813X.

Tento text vznikl jako součást řešení projektu Grantové agentury České republiky „Narativní konstrukce židovských identit“، (č. 401/06/P290). 
pravicových uskupení či v nostalgických vzpomínkách na ztracenou minulost, jež však pravděpodobně nikdy nebyla zcela uzavřená a monokulturní. ${ }^{1}$ Tato epizoda, již Boyarin dál nekomentuje, stojí na konci jeho textu jako alegorie, která má jaksi sama vyjevit pointu postihující povahu židovské (kolektivní) existence v diaspoře v jednadvacátém století. At' už měl Boyarin touto alegorií na mysli cokoliv, své uvažování o diskurzu diaspory uvádím jeho krátkým př́během z dvojího důvodu. Na jedné straně tento příběh výstižně sumarizuje rysy, jež jsou s diasporami obvykle spojovány; na straně druhé naznačuje, kde se od těchto, v každodenním i v akademickém diskurzu běžně sdílených, významů Boyarin oddaluje, čím tyto významy doplňuje a cestou jaké re-interpretace formuje svůj vlastní diskurz o diasporách. Předkládaný text se zaměřuje právě na tato doplňování a reinterpretace významu diaspory, tak jak je v několika svých dílech navrhli Jonathan a Daniel Boyarinovi. Texty bratrů Boyarinových stály na samém počátku vzniku tzv. diskurzu o diasporách na počátku devadesátých let dvacátého století ${ }^{2}$ a byly v mnoha ohledech formativní pro uvažování o diasporách v post-koloniální a kritické sociální teorii. V tomto př́spěvku se na ně soustřed'uji se záměrem představit diskurz, který diasporu hodnotí a interpretuje jako popis i jako model života ve společenství, jenž zároveň umožňuje její teoretické uchopení v souvislosti s dynamicky chápanými intersubjektivně sdílenými identitami.

\section{Svět diaspory}

Podívejme se tedy na alegorický příběh Jonathana Boyarina. Co nám tento příběh říká o diaspoře obecně? Jeho „hlavními hrdiny“ jsou Chasidové žijící v New Yorku, na něž se Boyarin zaměřil v polovině devadesátých let 20. století. Jako kolektivní subjekt představují Chasidové jednu z mnoha komunit Ž/židů žijících po celém světě v rozptýlení, tedy v diaspoře. Jejich ,úprk“ z jednoho nástupiště na druhé asociuje významy, jež slovníková a encyklopedická hesla spojují většinou s diasporou na jedné straně jako s událostí/procesem rozptýlení určitého (nejčastěji židovského) lidu, na straně druhé jako se samotnou komunitou žijící v tomto stavu. Těmito významy jsou odchod či útěk z mateřské země: ${ }^{3}$ dobrovolné opuštění země původu (záměrné proudění) nebo nucený exil (násilná migrace). ${ }^{4}$ Reprezentuje-li se diaspora př́iběhem ukazujícím svět v jeho každodenní atmosféře, je-li život v diaspoře přiblížen

Tedy neexistovala v podobě uzavřeného a monokulturního Gemeinschaftu.

2 Pro teoretickou analýzu diskurzu o diasporách viz Clifford 1997.

3 Srovnej např́klad následující slovníky a encyklopedie: Helena Pavlincová a Břetislav Horyna (eds.). 2003. Judaismus, křest'anství, islám. Olomouc: Nakladatelství Olomouc; Ja'akov Newman a Gavri'el Sivan. 1992. Judaismus od a do Z. Praha: Sefer; Encyclopaedia Judaica, vol. 6. 1971. Jerusalem: Keter Publishing House Ltd; The Jewish Encyclopedia, vol. 4. 1901. New York: Ktav Publishing House; Reallexikon für Antike und Christentum, Band III. 1957, Stuttgart: Anton Hiersemann; Die Religion in Geschichte und Gegenwart. Handwörterbuch für Theologie und Religionswissenschaft, Band II. 1958. Tübingen: J. C. B. Mohr (Paul Siebeck); Magyar Értelmezö kéziszótár (Mad’arský výkladový slovník). 2003. Budapest: Akadémiai Kiadó.

4 Již v samotném etymologickém základu řeckého slovesa diaspeírein můžeme nalézt možnost dvojího čtení významu rozptýlení, jestliže ho budeme překládat jako rozhazování či rozsévání semen (scattering or sowing of seeds), přičemž při alegorické výměně semena za konkrétní lid může 
pomocí skoro již banální událostí, jež může být z hlediska symbolické konstituce životního světa dané komunity marginální (nebot' co je shon ve velkoměstské dopravní situaci třeba v porovnání s nábožensky interpretovaným pohřbem charismatického vůdce, kolem nějž se soustřed’ovala mesianistická očekávání skupiny?), implicitně se zdůrazňuje nejspíše právě zmíněná významová dualita $\mathrm{v}$ pojmu diaspory. Tematická rezervovanost a deskriptivní charakter Boyarinova př́iběhu podněcují požadavek, aby nedošlo ke ztotožnění diaspory s exilem a s vyhnáním jako násilným přerušením a zlomem v životě dané komunity. ${ }^{5}$

Chasidové (užijeme-li zde této kategorie obecně, bez rozlišení jejích různých podskupin) mohou dále svým přesunem z jednoho místa na druhé v newyorském metru symbolizovat diasporu velice výmluvně nejen proto, že slovo diaspora bylo použito/vynalezeno původně pro historický případ rozptýlení Ž/židů pocházejících ze starověké Judeje, ale také z toho důvodu, že představují komunitu Ž/židů, která není rozptýlena pouze vzhledem k Izraeli, ale také vzhledem ke svým ,novým domovům“. V tomto př́ípadě jde o rozptýlení ve vztahu ke Spojeným státům, jež Chasidové v různých misijních vlnách opouštějí, aby zakládali své komunity jinde po světě (srovnej J. Boyarin 1996: 178). ${ }^{6}$ Dvojakost diaspory se zde projevuje $\mathrm{v}$ tom, že původně tragická interpretace údělu rozptýlení se v současném diskurzu chasidismu mění na imperativ rozptýlení.

Diaspora, jak dobře ukazují dlouhé dějiny židovských diaspor a jak alegoricky připomíná Boyarinova episoda, je flexibilní sociální strukturou. Znamená to, že na jedné straně se diaspora symbolicky konstituuje na základě reference $\mathrm{k}$ mytizované zemi původu, tj. k prvotním či novějším mytickým/mytizovaným teritoriím. ${ }^{7} \mathrm{Na}$ straně druhé se diaspora $\mathrm{z}$ hlediska aktuálního životního světa komunit konstituuje na základě reference k sítově či řetězově propojeným místům (městům, velkoměstům, krajům), jež členové diaspory kontinuálně opouštějí či znovu-nalézají. Jinými slovy diaspora není sociální strukturou, jež by se symbolicky vázala na jeden centrální bod, a není ani sociální strukturou skládající se z centra a periferie, nebot' není vytvářena pohybem skupin lidí směřujících ze stejného a jediného centra do různých periferií. Stačí zde jen obecně připomenout historii evropských společností, které se v závislosti na takových faktorech, jako jsou napríklad ekonomické zájmy, míra osvícenosti a tolerance, nebo naopak míra xenofobie a antisemitismu, př́stupu židovských komunit otevíraly či uzavíraly a přičinily se ve velké míré o to, že se židovské diaspory pohybovaly mezi „periferiemi“ a skrze ně, a to opakovaně - činíce tak z pohybu „normalitu“ a nikoliv nevšední, př́ležitost-

rozházení semen evokovat negativní událost rozkladu komunity, setí semen pak navozovat pozitivní událost plodnosti - ,zasetím“ v cizích krajích vzniká nová kvalita života komunity.

5 Pro uchopení nedobrovolného exilu, z něj plynoucího údělu vykořeněnosti, bezdomovosti a zkušenosti spojené s bytím neustále na nevhodném místě existuje v židovské tradici zvláštní koncept vyjádřený termínem galut.

6 Pro diferenciaci chasidismu v rámci třetí historické fáze ortodoxního judaismu viz Brown 2000: 318-324.

7 Prvotním mytickým teritoriem může být Izrael, novějším mytickým teritoriem např́klad USA. Mytizaci zde přitom chápu jako interpretační proces, díky němuž významově vyzdvižené prostory a časy získávají sakrální, nevšední ráz, aby v sociálních/symbolických reprezentacích dané skupiny zaujaly diskurzivně signifikantní místo. 
né a krátkodobé opuštění domácího prostoru. Diaspora je v tomto smyslu potulnou sociální strukturou a její obyvatelé, jak je nazval Joseph Roth (2001), jsou pak potulnými Ž/židy (wandering Jews). ${ }^{8}$ At’ už je př́mým impulsem jejich potulného života vyčerpanost z neustálých konfliktů, jež přináší každodenní život, existenční či ekonomická nouze, nebo jakýsi instinkt neustálého bloudění, životy Ž/židů v Evropě a v USA podle Rotha dobře ukazují, že tito žili vždy bezpečněji $\mathrm{v}$ čase než v prostoru. $V$ prostoru totiž nejsou doma nikde, přestože lze jejich hroby nalézt na každém hřbitově (Roth 2001: 11). Nebo naopak: právě proto, že nejsou doma nikde, jsou jejich hroby rozptýlené po různých kulturách a v různých společnostech. A protože nejsou doma v prostoru, „stěhují se“ do časovosti, v níž je zabydluje jejich náboženský či sekulární mesianismus.

Zkušenost „,nebýt (prostorově) nikde doma“ je v Rothově textu ovšem přeznačena spíše jako požehnání než zatracení. V pohyblivém světě diaspor se životní světy sice vytváří specifickým způsobem, ale to ještě neznamená, že by pro Rotha byly vize diktované např́ílad sionismem či humanismem jako reálné alternativy pro praktický život přijatelnější. Čím jsou ale životní světy v diasporické situaci specifické? Roth na základě svých zkušeností z pobytu v berlínské židovské diaspoře popisuje, že to nejnutnější, co zde Ž/židé z východu potřebují, aby mohli uspořádat bohoslužbu, sestává všehovšudy z deseti dospělých mužů (minjan), jednoho kantora a vědění, jež umožňuje identifikovat mizrach, tedy orientaci k východu, k Jeruzalému. ${ }^{9}$ Všechno ostatní je v jejich životě improvizované: místo, kde se lidé v danou chvíli sejdou, je jejich synagogou, ulice, kde uzavírají své obchody, je jejich pracovním místem, malý stupínek $\mathrm{v}$ restaurační místnosti se zbytky domácího nábytku jejich kabaretem (Roth 2001: 74-75). Improvizovaný charakter nemá $v$ Rothově textu povahu něčeho diskreditovaného. Je popisován jako samozřejmý důsledek vědomí života vyznačovaného náhlými zvraty, čili důsledek vědomí toho, že člověk může být $\mathrm{v}$ kterémkoli momentě přinucen $\mathrm{k}$ či se může rozhodnout pro pokračování ve svém potulování světem. Provizorní, přechodný rys sociálních institucí (jako jsou obchodování, bohoslužba, zábava ad.) tedy nemusí být nutně pojímaný ve smyslu popření autentičnosti kultury. A to přesto, že improvizovanost a provizornost je nejspíš jedním z vážných důvodů toho, proč sionistický diskurz odmítá život v diaspoře jako nepravý a nehodnověrný. ${ }^{10}$

8 Joseph Roth ve své knize reportáží a esejů Wandering Jew nepoužívá tento termín specielně v souvislosti s tematizací diskurzu diaspory. V roli rozumějícího etnografa/žurnalisty popisuje Roth vymístěný a těžký život židovských komunit ve východní Evropě, v evropských velkoměstech (Vídeň, Berlín, Paříž) a ve Spojených státech v posledních letech výmarské republiky. Jelikož přitom klade důraz na migraci mezi těmito geografickými místy, na připravenost tzv. potulných Ž/židů kdykoliv odejít, odjet, odplout, lze jeho metaforický termín vsadit i do našeho teoretického kontextu, v němž uvažujeme obecně o diaspoře jako o sociální struktuře.

$9 \quad$ Roth popisuje situaci dvacátých let dvacátého století.

10 Na sionistický diskurz přitom samozřejmě nelze nahlížet jako na jednolitý celek. V různých fázích sionismu se formovala různá zdůvodnění odmítnutí života v diaspoře: ve formativním období sionismu vyvolávala sociálně-historická situace zcela jiné impulsy než například v některých podobách po-holocaustovského sionismu, v němž skutečnost vyhubení Ž/židů zcela diskreditovala možnost pokračování existence v diaspoře (srovnej např. Shimoni 1995). V raném sionismu, např́íklad 
Improvizovaný život (jako důsledek života v pohybu) může tedy představovat pozitivní hodnotu: diasporická komunita si může vytvořit svůj vlastní životní svět kdekoliv v rozptýlení. Tento význam lze vyčíst i z Boyarinova úryvku. Chasidové a Lubavičové představují v jeho př́běhu v prostředí Brooklynu specifické nositele jinakosti. Přesto zde mohou mít svůj domov, svůj vlastní životní svět: vlastní styl oblékání, vlastní kalendář s vlastními výjimečnými událostmi (pohřeb Schneersona). Svůj rytmus života přitom přizpůsobují rytmu, jenž je diktován New Yorkem (či přesněji řečeno ho s tímto rytmem harmonizují) - v našem případě jeho velkoměstskou dopravní špičkou. A zdá se, že také systém velkoměstské dopravy je pro ně př́větivým světem - jak jinak vysvětlit jejich náhlé rozhodnutí měnit nástupiště a přestoupit v poslední chvíli z červené linky 3 na zelenou linku 4 ? $^{11}$ Jak jinak vysvětlit jejich schopnost improvizovat $\mathrm{v}$ situaci, jež se vymyká navyklému řádu světa, než tak, že se v daném městě dobře vyznají, znají jeho cesty, ulice a zastávky, znají jeho pravděpodobnou logiku fungování stejně, jako jejich prapradědečkové ve východní Evropě znali stromy, kameny a kaluže vlastního dvorku. Newyorští Chasidové se jako diasporická skupina vymezují v Boyarinově episodě vůči etno-kulturním a náboženským skupinám představujícím v daném kontextu původní nerozptýlené domorodé skupiny. Právě Chasidové zde prostřednictvím svého etnonyma „vystupuji““ na pozadí kulturního prostředí New Yorku. Jsou zde od „domorodců“ (reprezentovaných anonymním, nekategorizovaným, neopomlčkovaným průvodčím) diskurzivně jasně odlišeni. Interakce, která mezi nimi a průvodčím probíhá, však ukazuje, že jejich život v provizorním rozptýlení není negací možnosti zabydlení se.

Zabydlení se v diaspoře navíc nemusí nutně předpokládat izolovaný prostor, jenž je od prostoru dominantní společnosti př́sně oddělený fyzickými a/či symbolickými hranicemi. Diaspora by neměla být ztotožňována s historicky dobře známými prrípady ghett. ${ }^{12}$ I Chasidové z našeho příběhu reprezentují diasporickou komunitu, která není do sebe hermeticky uzavřená, ale sdílí pulzující život velkoměsta, jež se stává (také) jejich „,novým domovem“. A jak se dozvídáme $\mathrm{z}$ jiných částí Boyarinova textu, $\mathrm{v}$ tomto případě nejde pouze o pouhé sdílení životního prostoru, tedy fyzického prostředí oproštěného od sociálních a symbolických vztahů podílejících se na utváření kultury. O neizolovaném charakteru chasidské diaspory nesvědčí jenom jejich viditelná a aktivní přítomnost v Brooklynu ani jejich využívání nejnovějších komunikačních technologií (mobilní telefony) i v rámci

v pojetí Rabbiho Mordecai Eliasberga, je diaspora místem morální degenerace, jelikož neumožňuje autentickou syntézu náboženství a haskaly. Harmonie mezi náboženstvím a sekulárním věděním je podle něj možné dosáhnout pouze v zemi Tóry, kterou neohrožuje př́tomnost nežidovských názorů a pojetí osvícenství (Ehud Luz 1988: 59-60). Je dále příznačné, že se v sionistickém diskursu používá spíše koncept galut (exil), než diaspora.

11 Jde o linky metra, jež mezi stanicemi Atlantic Avenue a Crown Heights jezdí paralelně. Děkuji na tomto místě Radimovi Maradovi za MTA mapu newyorského metra!

12 A přitom ani ghetta neznamenala vždy nutně život v izolaci - považujeme-li za ghetto např́klad starověkou židovskou diasporu v římě, vidíme, že jeho obyvatelé (mezi nimi především z otroctví osvobození jedinci, kteří získali římské občanství) byli v sociálním kontaktu s Římem, nebo že se v ulicích židovské diaspory častokrát objevovali př́slušníci jiných římských etnokulturních diaspor (Syřané, Řekové ad.). 
ryze religiózních událostí (pohřeb Schneersona), ale také jejich univerzalistická interpretace judaismu, $v$ jehož duchu má dávno očekávaný Mesiáš přijít pro každého a nikoliv jenom pro Ž/židy (J. Boyarin 1996: 177-178).

\section{Diskurz diaspory}

Mezi obecnými významy definujícími diasporu, jež bylo možné rekonstruovat na základě interpretace úvodní alegorické episody, lze nalézt spojující článek. Je jím chtěný a afirmativní charakter diaspory. Právě tento její rys rozvíjejí v teoretické rovině Jonathan a Daniel Boyarinovi, kteř́ diasporu netematizují pouze ve smyslu etnografické deskripce situace, ale také ve smyslu sociálně-politického projektu. ${ }^{13}$ Tomuto projektu přitom nelze plně porozumět, aniž by bylo stručně vysvětleno, jak je možné na historickém prŕíkladu židovské tradice a judaismu argumentovat pro zachování diaspory. $V$ jakém smyslu slova může být diaspora chtěnou a přijímanou sociální strukturou v kultuře, jež od začátku svého rozptýlení dlouhá staletí směřovala ke ztracené zemi jednak jako k symbolickému domovu, jednak jako $\mathrm{k}$ reálnému prostoru návratu, jehož znovuzískání má diasporický stav ukončit? V jakém smyslu lze argumentovat pro život v diasporních podmínkách paralelně s rozvojem restaurativních snah určitého lidu? A souhlasili by vůbec Boyarinové se zamlčenými předpoklady těchto otázek? Připomeneme-li náš úvodní alegorický př́běh, můžeme již tušit, že nikoliv.

Boyarinové v této souvislosti vycházejí z historické rekonstrukce židovské diaspory, aby poukázali na to, že diaspora nebyla $\mathrm{v}$ židovské tradici hodnocena a pojímána výlučně v souladu se zmíněnými restaurativními snahami. Svou obhajobu diaspory jako sociální struktury vhodné pro současný transnacionální svět podpírají proto Boyarinové historizujícím argumentem, podle nějž bylo príijetí diaspory součástí židovské kultury a judaismu ve stejné míre jako touha po ukončení rozptýlení prostřednictvím návratu do svaté země. Touha po opětovném shromáždění rozptýlených osob a komunit, tedy touha po naplnění myšlenky návratu, je sice $\mathrm{v}$ židovské tradici podpírána biblickými sliby či proroctvími (srovnej napřiklad Gruen 2002), ale, jak poukazují Boyarinové, interpretace soustředěné kolem této touhy představují pouze jednu vrstvu tradice. Konkrétněji řečeno, v židovské tradici lze nalézt dva typy narativ tematizujících vztah židovského lidu k území Izraele. První typ narativa tematizuje smysl pro zakořeněnost v této zemi, oslavuje organickou vazbu židovského lidu na dobyté a následně ztracené teritorium, a počítá proto s možností návratu. Tento typ narativa se stal formativním např́ílad pro moderní sionistický diskurz. Druhý typ narativa představuje opak příběhů o autochtonnosti: tematizuje totiž vzpomínky na zkušenosti spojené s príchodem odjinud. Tento typ narativa mluví o „dokonale“ deteritorializovaném nomádickém lidu, který dokonce i do „své vlastní země“ přichází zvenčí. Tento nomádický lid není provždy spojen s partikulárním územím, ale nachází se v neustálé ne-usazenosti a právě v této ne-usazenosti nalézá sebe sama. Druhý typ narativa se objevuje napríklad v diskurzech vymezujících židovství jako bloudící a potulný národ, respektive v diskurzech pojímajících židovství jako společenství lidí, jejichž domov má textuální podobu, a proto je kdykoliv přemístitelný.

13 Při rekonstrukci a interpretaci teorie diaspory bratrů Boyarinových vycházím v prvé řadě z jejich textu „Diaspora: Generation and the Ground of Jewish Identity“. Kde bude třeba, upozorním na pozdější modifikace respektive její doplnění v pozdějších textech. 
Boyarinové poukazují nejen na to, že narativa a vzpomínky na kontinuální přicházení odjinud, respektive narativa a vzpomínky na kontinuální odchod jinam, byly a jsou v židovské tradici potlačovány (např́ílad sionistickým diskurzem). ${ }^{14}$ Snaží se navíc zamlčené či umlčované vrstvy této tradice ,rehabilitovat“ a argumentovat pro diasporu jako pro její integrální součást a na tomto základě legitimizovat diasporu jako sociální strukturu vhodnou (také) pro současný svět. Diaspora jako sociální struktura je podle nich kulturní analogií původního nomádismu židovského lidu, jakýmsi pokračováním materiálních a sociálních podmínek skupinové existence, jež je osvobozena od „břemena“ vázání se na nějaké konkrétní území (Boyarin a Boyarin 1993: 714-718). Ve vztahu k hermeneutické strategii Boyarinů je možná překvapivé, že pro podložení svých argumentů sahají i oni, sami představitelé kritické teorie a kritici nacionalistických diskurzů, $\mathrm{k}$ historické minulosti jako $\mathrm{k}$ legitimačnímu prostředku: diaspora je (dnes) príijatelná a přijetíhodná, jelikož není ničím novým, jelikož existovala plnohodnotně i dříve. Jinými slovy zdá se, že diaspora jako sociálně-politický projekt musí být legitimizovaná autoritou minulosti, silou minulých historických př́kladů.

Diaspora je tedy podle Boyarinů sociálně-politickou strukturou, jež byla formativní v minulých historických obdobích a jež zároveň vyhovuje současnému transnacionálnímu světu. ${ }^{15}$ Mluví o ní jako o určitém modelu vhodném pro svět protínajících se sítí, a to v duchu artikulace určitého sociálně-politického projektu, jenž může být opravdu plodný jen tehdy, pokud bude $\mathrm{v}$ souladu se specificky židovským kontextem, v němž se původně objevil (Boyarin a Boyarin 2002: 7). Tímto víceméně autoritativním odkazem na židovskou kulturní tradici sdělují Boyarinové vlastně dvě věci. Na jedné straně zdůrazňují své přesvědčení o nepostradatelné roli tzv. židovských studií pro širší vědeckou komunitu kulturních studií (Boyarin a Boyarin 1997). To, že se původně židovský koncept diaspory stal začátkem devadesátých let dvacátého století paradigmatickým modelem bádání zabývajícího se post-kolonialismem a migrací, ${ }^{16}$ je jen jedním z plodných př́kladů toho, proč je podle nich třeba otevřít brány tzv. židovských studií interdisciplinárnímu bádání. Na straně druhé vyslovují Boyarinovi kritiku

14 Za zmínku stojí, že explicitní a/či implicitní umlčování jedné vrstvy židovské tradice není specifikem pouze ideologických a politických diskurzi̊, jelikož rysy tohoto umlčování lze najít také v akademických odborných textech. Dobrým př́kladem ilustrujícím prosakování ideologických pozic do vědeckého diskurzu může být názor, jež skutečnost, že Ž/židé historicky vzato nikdy nemluvili stejným jazykem a většinou neobývali výlučně jedno území, hodnotí jako handicap. Diaspora je tím jednostranně diskreditovaná a nepřipouští se její pozitivní kulturotvorný význam (viz například Čapková 2005).

15 Boyarinové ve svých textech sdílí význam transnacionalismu, jenž se etabloval v posledním desetiletí v diskurzu sociologie a sociální antropologie (viz např́iklad Hannerz 1996) a v tomto smyslu o něm mluví i tento text. Transnacionální je svět, který existuje napříč (státními, národními) hranicemi a je propojen různými sítěmi sociálních vztahů: aktéři žijící v transnacionálním proudění se pohybují mezi svými původními a novými „domovy“ a tato místa usouvztažňují prostřednictvím udržování činnosti některých sociálních institucí, jako jsou například př́ibuzenství, obchod, náboženství či politika (srovnej Glick Schiller a Fouron 2001). Důležité přitom je, že v transnacionálním světě se nepohybují pouze subjekty, ale také kapitály, technologie, ideje a obrazy.

16 Pro kritickou interpretaci toho, jak je diaspora pojímána v kulturních studiích a post-koloniálním diskurzu, viz např́íklad Friedman 2002. 
těch teorií diaspor, které při konceptualizaci diaspory a interpretaci současných diasporických identit a životních situací opomíjejí komparaci s formativním rámcem židovské diaspory, respektive reprodukují již zmíněné umlčování jedné vrstvy židovské kultury (srovnej např́íklad Hall 2003). Nejde jim přitom o uznání ústřednosti či logické priority židovské diaspory, nýbrž o varování před zbytečnými hermeneutickými oklikami, respektive o připomenutí teoretického nebezpečí, jež může plynout $\mathrm{z}$ opominutí klíčových aspektů a úvah v komparativních diasporních studiích (Boyarin a Boyarin 2002: 10-11).

Podívejme se ted’ podrobněji na „projekt“ diaspory artikulovaný na základě židovského historicko-kulturního kontextu. Jako sociální struktura nabízí diaspora podle bratrů Boyarinových možnost, jak zachovat smysl pro sociální spravedlnost na poli etnokulturních vztahů a jak zároveň obhájit legitimitu kolektivní existence (židovské či jakékoliv jiné) vůči diskurzu radikálního individualismu. Na jedné straně je jejich kritické uvažování o diaspoře implicitně artikulovanou reakcí na etnokulturní konflikty (Izrael, Balkán), jejichž řešení nemusí podle nich nutně odsouvat ideál sociální spravedlnosti do sféry čisté utopie. Na straně druhé reagují kriticky na diskurz individualismu, jenž označuje jakoukoliv kulturní identitu zakládající se na sdíleném genealogickém původu za implicitně rasistickou. Boyarinové se pomocí kulturně-historické (re)interpretace či re-konstrukce židovské diaspory snaží ukázat, že přijetím diaspory jako modelu sociální struktury vhodné pro transnacionální a vzájemně propojený svět současnosti můžeme úspěšně diskreditovat donucovací univerzalistické diskurzy, jako je např́íklad rasismus či sexismus, a zachovat přitom legitimitu zavázanosti určitému společenství. Jinými slovy argumentují tím, že genealogické kulturní systémy soustředěné kolem jednoho či více významných předků nepředstavují nutně nesnášenlivé a etnocentrické skupiny tíhnoucí $\mathrm{k}$ politické hegemonii $\mathrm{v}$ etnokulturně rozmanitém sociálním prostoru. $\mathrm{V}$ př́ípadě genealogických kulturních systémů není totiž rozhodujícím faktorem samotná soustředěnost etnokulturní skupiny na linii vlastních předků, nýbrž typy kulturních interpretací a praktik, které se $\mathrm{k}$ této soustředěnosti vážou - tedy jejich žitá podoba.

Teoreticky vzato by pozitivní alternativou genealogických kulturních systémů, jež jsou současnými sociálně-vědnými teoriemi kvůli biologicky definovanému členství většinou považované za vylučující či přímo rasistické, mohly být kulturní systémy vybudované v souladu s diskurzem křest’anského humanismu, jehož myšlenkové základy lze najít u Pavla. To, že se diskurz křest’anského humanismu zakládá na ideálu rozšíření lásky na každého, tj. otevírá se společenstvím patř́í́m do jiných genealogických systémů, je ale podle Boyarinů jen jednou (v určitém smyslu povrchní) stránkou mince. Pavlova nedůvěra vůči tělesnosti a jeho hermeneutika alegorické genealogie není totiž podle jejich interpretace jednoznačným př́íkladem přijetí jinakosti, nebot' za ideálem univerzálně aplikovatelné lásky se skrývá imperialistická donucovací síla nutící k přijetí členství v křest’anské komunitě: ${ }^{17}$ odmítnutím integrativního gesta lásky se člověk stává nositelem neshody, chaosu a nepřijatelné jinakosti. ${ }^{18}$ Alegorická genealogie křest’anského univerzalismu, v níž je prostřednictvím instituce křestu individuální

17 Na tomto místě vycházejí bratři Boyarinové z analýzy Elizabeth A. Castelli, která ve své knize Imitating Paul: A Discourse of Power mluví o pavlovském univerzalismu jako o zamaskované vůli k moci. Cit. dle Boyarin a Boyarin 1993: 696. 
tělo nahrazeno tělem Kristovým (Boyarin a Boyarin 1993: 695), nemůže být tedy alternativou, kterou hledají. Bratři Boyarinové se ale u dekonstrukce křest’anského humanismu nezastavují a jdou ve své kritice dál. Ukazují, že komparativně vzato na tom nejsou, co se snášenlivosti týče, lépe ani kulturní systémy, které se zakládají na autochtonnosti etnokulturních skupin - tedy např́íklad ta vrstva židovské tradice, jež zdůrazňováním své neoddělitelnosti od území Izraele může realizovat vlastní zakořeněnost jenom za předpokladu vyloučení jiných společenstev potenciálně si nárokujících stejné teritorium. Snaha uniformě začlenit variabilitu kulturních specifik do jedné univerzální kultury je stejně problematická jako nekompromisní tíhnutí k etnické partikulárnosti (viz také D. Boyarin 1994). Shrnout komparativní analýzu těchto dvou diskurzů lze nejlépe Boyarinovými slovy, jež dobře vystihují vnitřní ambivalenci obou: „Genialita křestanství spočívá v jeho zájmu o všechny lidi obývající tento svět; genialita judaismu leží v jeho schopnosti ponechat druhé sobě samým“ (Boyarin a Boyarin 1993: 707). Odvrácenou, neblahou stránku této geniality můžeme na základě výše popsaných souvislostí lehce domyslet.

Je-li etnokulturní nesnášenlivost důsledkem úzké vázanosti na určité teritorium, mohly by řešení nabídnout kulturní systémy, které se od teritoriální vázanosti osvobozují. Takto lze alespoň shrnout vyústění teorie bratrů Boyarinových. Je to podle nich právě život v diaspoře, jenž disponuje „osvobozujíci“ silou schopnou nejen rozpohybovat srostlost s určitým územím, ale také přetransformovat roli prostoru v symbolických rovinách formování daného společenství. Klíčové zde totiž je, že přestože identita diasporního společenství nepřerušuje kontakt se zemí „původu“ úplně, artikuluje svou existenci (spíše než na základě autochtonnosti) na základě reinterpretovaného modelu původu ve vztahu $\mathrm{k}$ rodině, $\mathrm{k}$ historii, ke vzpomínkám a k jednání. Jinými slovy reinterpretovaná genealogie se v teorii Boyarinových stává pozitivní alternativou omezující teritoriality.

Podmínkou plnohodnotné existence $\mathrm{v}$ diaspoře je podle nich nahrazení loajality $\mathrm{k}$ místu vzpomínkou na toto místo. Tato symbolická transformace je potřebná nejen z hlediska možnosti vypořádat se se ztrátou země, ale také z důvodu umožnění ztráty/odpoutání se od země. Tedy nikoliv politicko-právní vlastnictví Izraele, ale vzpomínky na něj a kulturní praktiky, jež jej zpř́tomňují, jsou pro existenci v diaspoře klíčové (Boyarin a Boyarin 1993: 719). Intersubjektivně sdílená vzpomínka diskurzivně akcentovaného místa předpokládá reinterpretovanou genealogii, v níž původ, přestože ze samotné své povahy vyžaduje určitý somatický referent umožňující kulturní konstrukci specifického „my“ (podrobněji viz D. Boyarin 1994), je denaturalizovaným původem sdílené historické paměti. ${ }^{19}$ Genealogické společenství denaturalizovaného původu se pak utváří prostřednictvím vzpomínání na místo, jež je díky vzdání se nároku na jeho mocenskou kontrolu symbolicky přemístěno do budoucnosti. ${ }^{20}$ Takové genealogické společenství může být prosté nesnášenlivého etnického partikularis-

19 V diasporních podmínkách je původ denaturalizován jednak prostřednictvím konverze do diasporické skupiny, jednak konstrukcí duálních či mnohonásobných diasporních identit, jež je podle Boyarinů pozitivně hodnocenou možností kombinace většího množství stejnou měrou partikulárních identit.

20 Takovým místem nemusí být samozřejmě nutně Izrael, ale jakýkoliv mytizovaný prostor, který v narativech vzpomínání určité skupiny figuruje jako vlast či domov. 
mu. Genealogie založená na aktu vzpomínání totiž není individualizovanou genealogií v tom smyslu slova, že by se zakládala na biologicky definovaném řetězci jednotlivců určených svými předky: genealogie paměti je alternativou genealogie jednotlivců určovaných svým biologickým původem a přiřazovaných autoritativně ke státem vymezeným teritoriím (srovnej J. Boyarin 2002: 131-132).

Genealogie založená na intersubjektivně sdílených vzpomínkách na určité místo může utvářet diasporické společenství za předpokladu předávání vzpomínek z jedné generace na druhou. ${ }^{21}$ Intersubjektivně sdílená vzpomínka je výsledkem tohoto předávání. Mluvit o generacích zároveň s genealogií pamětí je přitom klíčové, jelikož předávání paměti není pouhým jejím kopírováním. Generace je konkrétním časem a místem imaginace genealogické skupiny, je konkrétním časem a místem znovu-(sebe)-představování této skupiny - tedy časem a místem partikulární aktualizace, interpretace a oživení kulturní paměti. Jinými slovy kreativní síla diasporického společenství spočívá v jeho schopnosti si znovu-představit sám sebe (reimagining itself) (J. Boyarin 1996: 165). Imaginace zde přitom nezískává svůj význam jako synonymum pro vytváření fantazijních, nereálných či smyšlených kvalit a hodnot, ale jako tvưrčí akt výstavby intersubjektivně sdíleného světa. Dvojsmyslnost anglického slova „generation“ může svou inherentní metaforičností velice dobře poukázat na to, že diasporické společenství je bez „generace“ nemyslitelné. Diasporické společenství je stejně tak nemyslitelné bez generace jako skupiny disponující sdílenou historickou pamětí, jako bez generace/produkce kulturní paměti v podobě její imaginativní re-produkce.

Je-li tedy diasporická generace „příbuzenstvím“ lidí, kteří dělají náhodou stejné věci (srovnej Boyarin a Boyarin 1993: 704), kteří sdílí určitou pamět’ stejným způsobem, můžeme říci, že idea generace rozbíjí imaginární totalitu genealogické skupiny jako jednotného lidu existujícího od dob praotce-zakladatele až do současnosti. Přesněji řečeno tím, že mluvíme o generaci, vsazujeme tuto skupinu do konkrétního času a prostoru, chronologicky i geograficky ji konkretizujeme vždy v rámci partikulární intersubjektivity. $\mathrm{V}$ opozici $\mathrm{k}$ individuali-

$21 \quad$ Souvislost mezi genealogií a generací, respektive samotné místo pojmu generace v teorii bratrů Boyarinů bývá na základě jejich textu „Diaspora: Generation and the Ground of Jewish identity“ vykládáno různě. Pro nejednoznačnost práce s těmito pojmy může být symptomatické, že v bibliografii Jamese Clifforda (1997: 372) nalezneme překlep (či přeřeknutí?) zrovna u slova „generation“: Clifford či jeho asistent přejmenovali původní text bratrů Boyarinů na „Diaspora: Generational Ground of Jewish Identity“. V jakém smyslu je tedy v rámci jejich teorie „,generace“ záhadným místem? Jana Evans Braziel a Anita Mannur (2003: 85-86) např́klad interpretují genealogii a generaci jako principy, které se navzájem vylučují. Židovská diaspora podle nich nabízí vizi intersubjektivně sdílené identity, která není určená ani geograficky (teritoriálně), ani genealogicky. Na místo geografických a genealogických vazeb se diaspora v jejich interpretaci zakládá spíše na generačních vztazích a právě díky tomu je s to nabídnout otevřenou a flexibilní verzi židovských identit. Mému výkladu je bližší interpretace Jamese Clifforda, který genealogii a generaci v teorii Boyarinů chápe jako synonyma (1997: 272). Podotýká přitom, že Boyarinové se nevyjadřují př́mo ke specifickým mechanismům genealogie a generace, tedy toho, jakými mechanismy může být diaspora založena na vzpomínkách, historii, rodině. Teoretické ztotožnění genealogie a generace proto nelze dostatečně jasně vysvětlit. Na základě srovnání dalších textů Boyarinových (D. Boyarin 1994, J. Boyarin 1996, Boyarin a Boyarin 2002) se, jak uvidíme dále, přikláním k tomu, že generačně založená diasporní identita má být tematizována $\mathrm{v}$ rámci reinterpretovaného modelu genealogie. 
zované genealogii představuje generace, tímto způsobem vyčleňovaná z genealogie paměti, intersubjektivní a otevřenou sociální strukturu. Její součástí se může stát každý, kdo vstoupí do společenství sdíleného vzpomínání a zapomínání, aniž by se přitom musel odvolávat na své předky jako na subjekty, jež jeho vstup do daného společenství autorizují.

\section{Skryté možnosti diaspory - závěr}

Charakterizujeme-li diasporu jako místo imaginace, v jehož rámci jsou diasporické identity konstituovány (srovnej J. Boyarin 1996: 165), bude třeba analyticky rozlišit mezi diasporou jako sociální strukturou a diasporickou identitou. Bratři Boyarinové tematizují obě možnosti. Zatímco diaspora jako sociální struktura vyjadřuje rozptýlení lidí a společenství ve světě na základě jejich vztahu k reálnému či mytickému teritoriu, vůči němuž se diasporické skupiny v geografickém a v sociálním prostoru vymezují, diasporická identita je rozkládající se a rozptýlená v tom smyslu slova, že umožňuje „,soužití“ mnoha parciálních identit jedince. Jde o „soužití“ dílčích identit, které nejsou ,žity“ vždy zároveň, ale vztahují se k praktikám a jednáním, jež jedinec provádí v závislosti na konkrétních situacích či sociálních interakcích. Diasporickou identitu přitom není třeba nutně vymezovat jenom v etnokulturním smyslu slova, může být totiž také př́ípadem jiných, např́klad genderových, identit:

Být ženou je určitým zvláštním typem bytí a existuje mnoho stránek života a mnoho životních praktik, které tuto zvláštnost zdůrazňují a oslavují ji. To ovšem nutně neimplikuje pevné ukotvení či zmrazení veškerého jednání a projevů genderově vymezené identity v jednom souboru parametrů. Lidské bytosti se dělí na muže a ženy z určitých důvodů, toto rozdělení však nevystihuje celý př́běh jejich tělesné identity.

(Boyarin a Boyarin 1993: 721)

Úzkou souvislost mezi diasporou jako sociální strukturou a diasporickou identitou pak můžeme odkrýt poukazem na specifický charakter diaspory jako sociální struktury, jež činí diasporickou identitu možnou. Diaspory totiž nepředstavují hermeticky uzavřené životní světy, ale existují a existovaly v dialogu se svým prostředím. Život v diaspoře, respektive příchod a odchod určité diaspory, neznamená popření participace v širším socio-kulturním prostředí. Zdá se, že podle Boyarinů je tomu tak i navzdory historickým př́kladům etnokulturních konfliktů a pogromů, jež takovou participaci činily prakticky nemožnou a zmařily zároveň pravděpodobnost výskytu sociálních interakcí, v nichž se diasporické identity mohou konstituovat. Bez reflexe stinné stránky života $\mathrm{v}$ diaspoře je

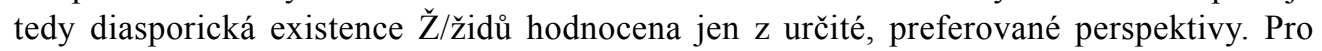
kritické shrnutí teorie bratrů Boyarinů to znamená dvě věci. Na jedné straně jde o to, že při formulaci svých představ o diaspoře Boyarinové vědomě vycházejí z historicko-kulturní podoby židovské minulosti, ze situací, v nichž Ž/židé žili v relativním klidu a nebyli perzekuováni - akcentují tedy situace, v nichž př́tomnost židovské diaspory a specificky židovská kreativita nebyly vnímány jako nepřátelský prvek ohrožující dominantní kulturu (Boyarin a Boyarin 1993: 711). Taková idealizace diaspory odráźí eticko-politický postoj bratrů Boyarinových, je tedy artikulací určité ideologie, kterou lze odkrýt za většinou teorií formulovaných v akademických diskurzech. Pokud připomeneme, že jedním ze základních rysů sionismu bylo historické ztvárnění exilu jako období perzekuce, utlačování, poko- 
ření a utrpení, jež má svůj protipól ve starověku jako v období politické, sociální a kulturní autonomie židovského lidu (srovnej Zerubavel 1995), bude možné teorii Boyarinů charakterizovat perspektivou odvetné vzpomínky (counter-memory): Boyarinovi v této souvislosti artikulují typ vzpomínání, jež vystupuje proti prevládajícímu typu sionistické paměti. Idealizaci diaspory lze přitom považovat za tenký led jejich teorie, jelikož se díky ní relativizuje jistota, se kterou je diaspora současnému transnacionálnímu světu nabízena jako etnokulturně heterogenní sociální struktura, jež není donucovací, ale respektující. Idealizace diaspory zároveň podporuje její univerzalizaci, a to na úkor zkušeností jedinců či společenstev, již existenci $v$ diasporicky rozpohybovaném světě přes všechny její teoretické výhody zakouší přece jen jako vykořeněnost, bezdomovost, dezorientaci. V této souvislosti se nám teorie Boyarinových může ukazovat jako málo sociologická, jelikož opomíjí př́ípady, v nichž stejná, objektivně definovaná sociální struktura dává vzniknout zcela odlišným zkušenostem a životním světům. Sociální struktura diaspory a diasporická identita se tak ukazují jako koncepty formulované z hlediska pozorovatele, jehož perspektivu nemusí sdílet všichni, kteří v diasporické situaci žijí.

Na straně druhé nám ale idealizace diaspory ukazuje, že z hlediska historicko-kulturní analýzy je situace poněkud složitější. Při kritické interpretaci teorie bratrů Boyarinů totiž nesmíme zapomenout na to, že selektivním důrazem na idealizovanou pozitivní stránku diaspory měli Boyarinové v úmyslu rekonstruovat a znovu-zpřitomnit ten aspekt židovských diaspor, který bývá častokrát opomíjen. Diaspora totiž není jenom nuceným rozptýlením, ale také svobodně zvolenou alternativou, jež může rozptýleným společenstvím přinášet mnohé výhody (kulturní kontakty, možnosti obchodování, „osvobozeni““ se z nátlaku „vlastní“ skupiny atd.). Diaspora tedy není ztotožnitelná se znehodnocením či popřením jakési esence židovské kultury neboli s churavou situací, jež nutně potřebuje ozdravný program zabezpečený například sionistickým ideálem znovu-založení Izraele a ukončení rozptýleného stavu (srovnej D. Boyarin 1994).

Diaspora ve formulaci bratrů Boyarinových je strategií nestátnosti. Pokud se židovské (či jakékoliv jiné) diaspory potřebují v kulturním či sociálním smyslu slova regenerovat, diaspora jim nabízí strategii kulturních a politických identit, jež nejsou zakotvené ve výlučné kontrole politicky ohraničeného území, a nejsou proto destruktivní. V tomto podle Boyarinů spočívá pozitivní síla diaspory.

Přes zmíněnou idealizaci diaspory však Boyarinové ve svých pozdějších textech poukazují i na to, že diaspora není všemohoucí. Přestože je diaspora v podmínkách transnacionálního proudění takovým modelem sociální struktury a identity, jenž může korigovat nedostatky praktických dopadů sociálního uspořádání diktovaného národním státem, nelze z ní učinit univerzální model, jenž by byl aplikovatelný na všechny sociální kontexty. Za neplodný, jak už bylo výše zmíněno, zároveň považují takový teoretický model, který diasporu univerzalizuje tím, že ji oproštuje od kulturně-historických souvislostí židovství. Podle Boyarinů vede právě toto zjednodušování („vyčištění“) diaspory k opomíjení rizik, jež v sobě diaspory nesou (Boyarin a Boyarin 2002), bez jejichž reflexe se však může stát aplikace diaspory jako modelu pro transnacionální svět problematickou.

$\mathrm{Na}$ tato rizika lze dobře upozornit poukazem na interpretace židovských kulturních narativ. Jonathan Boyarin se vydal cestou interpretace pasáže z babylónského Talmudu a příběhu pocházejícího z lidové tradice Ž/židů mluvících jidiš, aby přiblížil paradoxní a na 
první pohled neviditelné možnosti, které se v diaspoře skrývají. Paradoxní jsou tyto možnosti proto, že jejich ambivalence vyvěrá ze stejného základu. Podívejme se na ně závěrem trochu podrobněji, aby bylo možné objasnit, proč se diaspora jako model života ve společenství pohybuje mezi snem a realizovatelným projektem sociálně-politického uspořádání. Dvě zmíněná narativa slouží Boyarinovi jako textuální vrstvy židovské tradice, které hermeneuticky odhalují skutečnost, že odpovědí na genealogicky kladenou otázku po identitě židovství je její dvojakost a nejednoznačnost. Talmudická pasáž připomíná Izraeli, že nebyl Bohem zvolen pro vlastní velikost (greatness) či kvalitu převyšující jiné národy, přičemž právě připomínání a uvědomování si této skutečnosti Abrahamem, Mojžíšem, Áronem a Davidem činí židovský lid velikým. Pokora, jíž se vyznačuje schopnost a ochota označit sebe sama za prach, popel, červa či prímo za nic (nothing), je silnou stránkou Izraele, stránkou, jež ukotvuje specifický vztah židovského lidu k Bohu. Podle Boyarina vypovídá tento př́běh na jedné straně o moudrosti, jež je s to si uvědomovat význam nicotnosti. Na straně druhé je ale tento př́běh zároveň do sebe obráceným ironickým žertem, nebot' zbožné přihlašování se $\mathrm{k}$ pokoře je $\mathrm{v}$ něm podkopáváno neustálým důrazem na to, jak pokorný Izrael vlastně je v porovnání s jinými národy. Ambivalenci, na niž chce tento príběh poukázat, lze tedy shrnout takto: uznání vlastní nicotnosti činí jedince/společenství významným („někým“) - přiznání si vlastní nicotnosti vyzdvihuje jedince/společenství z okruhu ostatních v hierarchickém smyslu slova a vytváŕí tak jeho odlišnost. Platí zároveň, že jedinec/ společenství musí být někým/něčím, tedy musí být hierarchicky odlišený/é (distinguished), aby mohl/o být nikým.

Tuto ambivalenci velice dobře ilustruje i druhý Boyarinem interpretovaný př́iběh. Mluví se v něm o svátku Jom kipur, jak ho slaví jedno ze společenstev mluvících jidiš. Když v rámci svátečního rituálu dosahuje den smíření svého vrcholného okamžiku, rabín vyjádří svoje pokání tím, že náhle padne na zem a volá: „Můj Bože, jsem nic!“ (Lord, I am nothing!) Chvíli po něm prostraci a volání opakuje kantor. Když pak za okamžik padne na zem a zavolá stejně i hrobník, podívají se rabín a kantor pohrdavě na sebe a ř́íkají: „Tak podívej se, kdo si tady myslí, že je nic!“ (Boyarin a Boyarin 2002: 1-4). Pokora se zde bezprostředně mění ve zpupnost, sebe-ponížení a reflexe vlastní nedokonalosti v distinkci, jež není volně dostupná všem a není reprodukovatelná z vlastní vůle jedince.

Podobně se i diasporická identita a touto identitou poznamenaná odlišnost v post-koloniálních teoriích diaspory mnohdy mění v distinkci. Diasporická identita se navíc stává oslavovanou a výjimečnou hodnotou osvojenou sociálními aktéry v podobě jakéhosi módního emblému identity. Boyarinové upozorňují na toto riziko a snaží se mu vyhnout načrtnutím možnosti ironické sebe-reflexe, jejímž př́kladem jsou i výše převyprávěná narativa židovské kultury. Ze sociologického hlediska je na výše uvedeném zajímavé to, že boyarinovskou interpretaci těchto dvou př́iběhů můžeme číst nejen jako př́spěvek do teoretických diskusí sociálně-vědného diskurzu o diasporách, ale zároveň jako konkrétní př́iklad toho, jak se na základě imaginativní re-produkce/re-interpretace židovské tradice produkuje kulturní pamět' a jak se tím zhmotňuje představa diasporického společenství konstituovaného na sdíleném vzpomínání a zapomínání. Prolínáním roviny sociálně-politického projektu a roviny sociálně-vědné reflexe se zde konstituuje pozorovatel disponující diasporickou identitou, jenž se pohybuje mezi interpretací a utvářením interpretovaného fenoménu. 


\section{Věnování}

Tento text věnuji svému, v době jeho vzniku nenarozenému, dítěti, které mi během psaní velice intenzivně naznačovalo, že ,pohyb není pouze prostředkem přemíst'ování z místa na místo“ (viz call for papers tohoto čísla Sociálních studii). Pohyb je komunikace, pohyb je protest. Pohyb je přivolání hudby.

\section{Literatura}

Boyarin, D.; Boyarin, J. 1993. „Diaspora: Generation and the Ground of Jewish Identity.“ Critical Inquiry, 19 (4): 693-725.

Boyarin, D.; Boyarin, J. 2002. Powers of Diaspora. Minneapolis-London: University of Minnesota Press.

Boyarin, D. 1994. A Radical Jew: Paul and the Politics of Identity. Berkeley: University of California Press.

Boyarin, J. 1996. Thinking in Jewish. Chicago: The University of Chicago Press.

Boyarin, J.; Boyarin, D. (eds.) 1997. Jews and Other Differences. The New Jewish Cultural Studies. Minneapolis-London: University of Minnesota Press.

Braziel, J. E.; Mannu, A. (eds.) 2003. Theorizing Diaspora. Oxford: Blackwell.

Brown, B. 2000. „Orthodox Judaism.“ In: J. Neusner a A. J. Avery-Peck (eds.) The Blackwell Companion to Judaism. Oxford: Blackwell, s. 311-333.

Clifford, J. 1997. Routes. Travel and Translation in the Late Twentieth Century. Cambridge, Mass.: Harvard University Press.

Čapková, K. 2005. Češi, Němci, Židé? Národní identita Židů v Čechách 1918-1938. Praha - Litomyšl: Paseka.

Friedman, J. 2002. „From Roots to Routes. Tropes for Trippers.“ Anthropological Theory, Vol 2 (1): 21-36.

Glick Schiller, N.; Fouron, G. E. 2001. Georges Woke Up Laughing. Long-Distance Nationalism and the Search for Home. Durham - London: Duke University Press.

Gruen, E. S. 2002. „Diaspora and Homeland.“ In H. Wettstein (ed.) Diaspora and Exiles. Varieties of Jewish Identities. Berkeley: University of California Press.

Hall, S. 2003. „Cultural Identity and Diaspora.“ In J. E. Braziel a A. Mannu (eds.) Theorizing Diaspora. Oxford: Blackwell.

Hannerz, U. 1996. Transnational Connections. Culture, People, Places. London: Routledge.

Luz, E. 1988. Parallels Meet. Religion and Nationalism in the Early Zionist Movement (1882-1904). Philadelphia a New York a Jerusalem: The Jewish Publication Society.

Roth, J. 2001. The Wandering Jews. London: Granta Books.

Shimoni, G. 1995. The Zionist Ideology. Hannover - London: Brandeis University Press.

Zerubavel, Y. 1995. Recovered Roots. Collective Memory and the Making of Israeli National Tradition. Chicago - London: The University of Chicago Press.

Slovníky a encyklopedie

Die Religion in Geschichte und Gegewart. Handwörterbuch für Theologie und Religionswissenschaft, Band II. 1958. Tübingen: J. C. B. Mohr (Paul Siebeck).

Encyclopaedia Judaica, vol. 6. 1971. Jerusalem: Keter Publishing House Ltd. 
Magyar Értelmező kéziszótár (Mad’arský výkladový slovník). 2003. Budapest: Akadémiai Kiadó. Newman, J.; Sivan, G. 1992. Judaismus od a do Z. Praha: Sefer.

Pavlincová, H.; Horyna, B. (eds.) 2003. Judaismus, křest'anství, islám. Olomouc: Nakladatelství Olomouc.

Reallexikon für Antike und Christentum, Band III. 1957, Stuttgart: Anton Hiersemann. The Jewish Encyclopedia, vol. 4. 1901. New York: Ktav Publishing House.

\section{Autorka}

Eleonóra Hamar, vzděláním socioložka a religionistka. Působí jako odborná asistentka na Ústavu religionistiky Filozofické fakulty Masarykovy univerzity. Zabývá se teoriemi narativní konstrukce, metodologií religionistického výzkumu a současnou religionistickou teorií. Její současná výzkumná činnost se zaměřuje na narativní konstrukci židovských identit. Kontakt: hamar@phil.muni.cz 